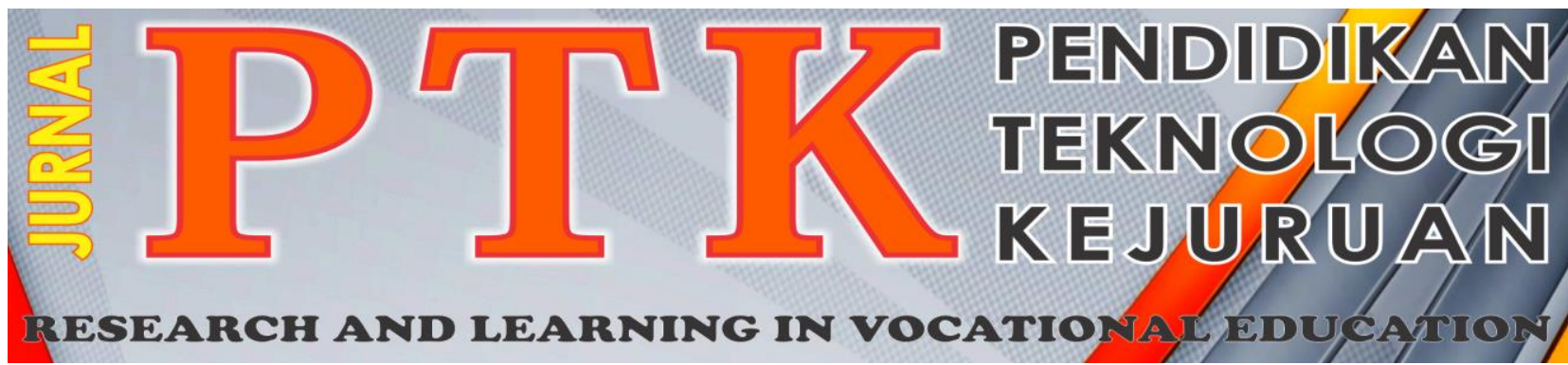

Vol. 2, No. 1 (2019)

P-ISSN: 2621-3273

E-ISSN: 2621-1548

\title{
Penerapan Video Media Interaktif untuk Meningkatkan Motivasi dan Hasil Belajar Shield Metal Arc Welding
}

\author{
Randa Avito Yasri ${ }^{1}$, Ambiyar ${ }^{2}$, dan Mulianti ${ }^{3}$ \\ ${ }^{123}$ Jurusan Teknik Mesin, Fakultas Teknik, Universitas Negeri Padang \\ ${ }^{*}$ Corresponding author, e-mail: randaavitoyasri@gmail.com ${ }^{1}$
}

\begin{abstract}
Abstrak - Penelitian ini membahas penerapan video sebagai media interaktif, motivasi belajar siswa dan hasil belajar siswa. Tujuan penelitian ini untuk motivasi dan hasil belajar siswa. Jenis penelitian ini adalah Penelitian Tindakan Kelas (PTK), Populasi dan Sampel yang digunakan pada kelas XI Teknik Pengelasan sebanyak 29 orang siswa. Intrumen yang digunakan berupa video media interaktif, lembaran observasi dan tes penguasaan. Data diperoleh dari motivasi belajar yaitu presentase dan hasil belajar adalah rata-rata. Motivasi belajar siswa pada siklus I pertemuan I adalah $50.86 \%$ dengan kriteria kurang termotivasi; siklus I pertemuan II adalah $64.22 \%$ dengan kriteria cukup termotivasi; dan pada siklus II pertemuan adalah I $73.71 \%$ dengan kriteria termotivasi; siklus II pertemuan adalah II 84.48\% dengan kriteria sangat termotivasi. Hasil belajar pada siklus I dengan rata-rata 70,24 dan siklus II dengan rata-rata 84,37. Penggunaan video sebagai media interaktif dapat meningkatkan motivasi dan hasil belajar Mata Pelajaran Shield Metal Arc Welding (SMAW) Kelas XI Teknik Pengelasan di SMK Negeri 1 Bukittinggi.
\end{abstract}

\section{Kata kunci : Motivasi, Hasil Belajar, Video, Media Interaktif, Shield Metal Arc Welding}

Abstract-This research explores the application of video as an interactive media, learning motivation of students and student learning outcomes. The purpose of this research for motivation and student learning outcomes. This type of research this is a class action Research (PTK), the population and the sample used at the class XI welding techniques as much as 29 students. The instruments used in the form of interactive media, video observation sheets and test of mastery. Data obtained from the motivation of learning i.e. the percentage and the results of the study are average. The learning motivation of students in cycle I meetings I was $50.86 \%$ criteria less motivated; the Icycle meeting II was $64.22 \%$ criteria sufficiently motivated; and in cycle II meeting was $73.71 \%$ criteria I motivated; cycle II II meeting was $84.48 \%$ criteria are very motivated. The results of a study on cycle I with an average of 70.24 and cycle II with an average of 84.37. The use of video as an interactive media can increase motivation and learning results Subjects Shield Metal Arc Welding (SMAW) Welding Technique Class XI in SMK Negeri 1 Bukittinggi.

Keywords: Motivation, Learning Results, Video, Interactive Media, Shield Metal Arc Welding

\section{Pendahuluan}

Perkembangan teknologi sekarang ini membutuhkan peningkatan kualitas Sumber Daya Manusia (SDM) melalui peningkatan kualitas tersebut adalah pendidikan. Pendidikan formal yang dapat menyiapkan sumber daya manusia yang terampil dan siap pakai ialah Sekolah Menengah Kejuruan [21]. Sekolah merupakan wadah proses belajar mengajar yang bertujuan untuk mengubah perilaku dan budi pekerti peserta didik [5]. Tempat bertemunya pendidik dengan yang didik ialah sekolah [14]. Belajar adalah proses perubahan individu yang berinteraksi dengan lingkungannya [3]. Pendidikan sebagai sarana penilaian hasil belajar yang mencakup aspek kognitif, afektif dan psikomotor [10]. Media interaktif digunakan untuk mengembangkan informasi yang berupa visual dan audio dikemas dalam mesin elektronik [7].

Perangkat pembelajaran dapat berupa visual dan audio berisikan materi pembelajaran [6]. Faktor 
ekternal berupa media pembelajaran dapat mempengaruhi minat belajar peserta didik [19] Motivasi merupakan proses mendorong peserta didik untuk meningkatkan Hasil belajar [20]. Motivasi belajar merupakan keinginan untuk berubah dalam proses pembelajaran kearah yang lebih baik [15]. Hasil belajar adalah hal yang diperoleh dari proses pembelajaran [11].

Berikut data nilai ujian MID semester I kelas XI Teknik Pengelasan.

Tabel 1. Nilai MID Semester I Kelas XI Teknik Pengelasan pada mata pelajaran Shield Metal Arc Welding di SMK Negeri 1 Bukittinggi Tahun Ajaran 2018/2019

\begin{tabular}{cccc}
\hline No & Nilai & $\begin{array}{c}\text { Jumlah Siswa } \\
\text { (Orang) }\end{array}$ & Persentase \\
\hline 1 & $<70$ & 16 & $55 \%$ \\
2 & $\geq 70$ & 13 & $45 \%$ \\
& Total & 29 & \\
\hline
\end{tabular}

Sumber : SMK Negeri 1 Bukittiinggi

Tabel diatas merupakan diidentifikasi masalah yang mempengaruhi motivasi dan hasil belajar Shield Metal Arc Welding siswa kelas XI Teknik Pengelasan SMK Negeri 1 Bukittinggi, yaitu:

1. Siswa kurang mempunyai perhatian penuh terhadap proses pembelajaran.

2. Media pembelajaran masih bergantung dengan media papan tulis dan proyektor pada mata pelajaran Shield Metal Arc Welding.

Penyampaian materi oleh guru yang kurang menarik perhatian siswa.

\section{METODE}

Jenis Penelitian yang dilaksanakan adalah Penelitian Tindakan Kelas (PTK). Jenis penelitian menggunakan metode penelitian tindakan (action research). Penelitian tindakan kelas merupakan kegitan yang didalam ada proses pencermatan terhadap kegitan yang sengaja dilakukan dalam prose pembelajaran didalam kelas [2]. John Elliot (Elliot,1982) menggambarkan adanya 3-5 aksi (tindakan). John Elliot mengemukakan pendapat tentang setiap aksi atau tindakan yang harus dilakukan dalam penelitian tindakan kelas membaginya menjadi beberapa langkah-langkah dalam persiklus, dijelaskan dalam gambar berikut ini

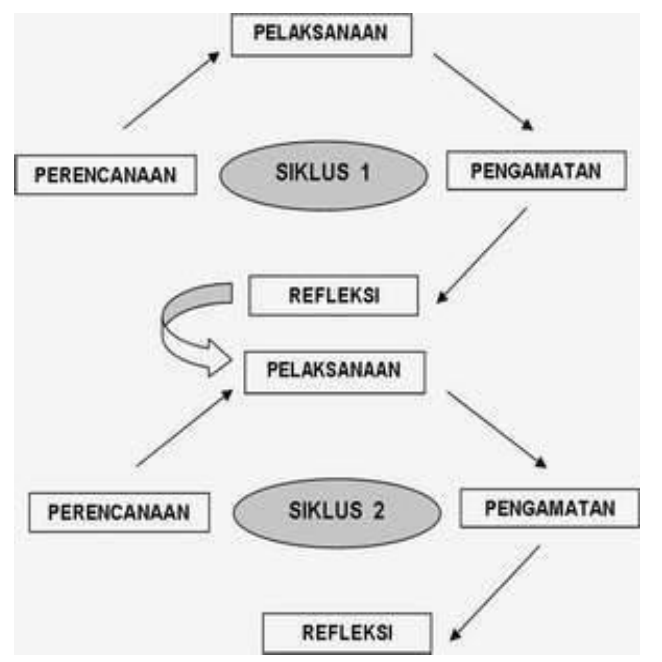

Gambar 1. Riset Aksi Model John Elliot Sumber:https://akhmadsudrajat.wordpress.com/2008 z3/21/penelitian-tindakan-kelas-part-ii/

\section{A. Prosedur Penelitian}

Penelitian tindakan kelas ini dilaksanakan pada siswa kelas XI Teknik Pengelasan SMK Negeri 1 Bukittinggi yang terdaftar pada semester I tahun pelajaran 2017/2018, dengan jumlah siswa laki-laki sebanyak 29 orang.Penelitian dilaksanakan pada pelaksanaan tindakan pada dilakukan pada kelas subjek penelitian. Responden diminta memperhatikan video media interaktif dan menjawab tes yang diberikan untuk mengetahui kualitas instrumen.

\section{B. Instrumen}

Instrumen yang telah dipilih memerlukan teknik pengumpulan data dalam pengaplikasiannya pada penelitian yang dilakukan. Mengumpulkan data merupakan pekerjaan penting dalam langkah penelitian. Data penelitian tindakan ini dikumpulkan dengan melakukan observasi atau lembar pengamatan dan hasil tes yang dapat diuraikan sebagai berikut:

\section{Observasi}

Observasi merupakan penilaian objek yang dilakukan pada kelas tempat penelitian [12]. Observasi adalah upaya untuk mengukur kemampuan objek yang diteliti menggunakan tes [2] Tes digunakan untuk memperkuat data hasil observasi selama pembelajaran terutama yang berkaitan dengan penguasaan materi pelajaran oleh siswa. pengumpulan data pada penelitian ini dapat ditunjukkan pada tabel 2 berikut: 
Tabel 2: Teknik Pengumpulan Data Penelitian

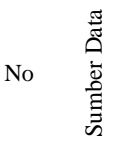

$$
\text { 泀 }
$$

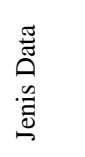

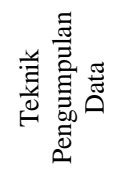

\begin{tabular}{cccccc}
\hline 1 & Siswa & $\begin{array}{c}\text { Motivasi } \\
\text { dalam } \\
\text { belajar }\end{array}$ & $\begin{array}{c}\text { Proses } \\
\text { Belajar }\end{array}$ & Observasi & $\begin{array}{c}\text { Lembar } \\
\text { observasi }\end{array}$ \\
\hline 3 & Siswa & Hasil belajar & $\begin{array}{c}\text { Ranah } \\
\text { Kognitif }\end{array}$ & Tes & Soal tes \\
\hline & Guru & $\begin{array}{c}\text { Penerapan } \\
\text { model } \\
\text { pembelajara } \\
\mathrm{n}\end{array}$ & $\begin{array}{c}\text { Penerapan } \\
\text { video media } \\
\text { interaktif }\end{array}$ & Observasi & $\begin{array}{c}\text { Lembar } \\
\text { observasi }\end{array}$ \\
\hline
\end{tabular}

\section{Lembaran Tes}

Lembar tes berupa objektif. Instrumen dirangkai serta dijabarkan berdasarkan indikator instrumen yang diukur merupakan hasil belajar (Sugiyono, 2012: 149)

\section{Teknik Analisis Data}

Data yang diperoleh dalam penelitian ini dianalisis dengan menggunakan teknik analisis kuantitatif sebagai berikut:

\section{Teknik Analisis Data Motivasi Belajar}

Motivasi belajar dihitung dengan presentase. rumus motivasi belajar [16] seperti berikut:

$$
\mathrm{P}=\frac{5}{n} \times 100 \%
$$

Keterangan:

$\mathrm{P}=$ angka presentase

$\mathrm{f}=$ frekuensi yang muncul

$\mathrm{N}=$ jumlah frekuensi atau banyaknya induvidu.

Data observasi mengenai motivasi belajar diambil dengan cara mengisi lembaran observasi dan menghitung dari peserta didik yang aktif dalam pembelajaran,

Kriteria penilaian menggunakan rating scale terlihat pada tabel 3 berikut:

Tabel 3: Kriteria Penilaian Motivasi Belajar Siswa

\begin{tabular}{ccc}
\hline & $\begin{array}{c}\text { Rentang Presentase } \\
\text { Hasil Motivasi Belajar } \\
\text { Nhield Metal Arc } \\
\text { Welding }(\%)\end{array}$ & Kategori \\
& $80 \leq \mathrm{P} \leq 100$ & Sangat Termotivasi \\
& $65 \leq \mathrm{P} \leq 79,99$ & Termotivasi \\
2 & $55 \leq \mathrm{P} \leq 64,99$ & Cukup Termotivasi \\
3 & $40 \leq \mathrm{P} \leq 54,99$ & Kurang Termotivasi \\
4 & $0 \leq \mathrm{P} \leq 39,99$ & Tidak Termotivasi \\
5 & & \\
\hline
\end{tabular}

2. Teknik Analisis Data Hasil Belajar

Hasil belajar didapatkan menggunakan cara tes untuk mengukur tingkat pemahaman siswa dengan materi. menghitung rata-rata hasil belajar digunakan rumus Suharsimi Arikunto [1] yaitu sebagai berikut :

$x=\frac{\sum x}{\mathrm{u}}$

Keterangan:

$x=$ Rata-rata (mean)

$\Sigma x=$ Jumlah seluruh skor

$\mathrm{n} \quad=$ Banyaknya subjek

Ada lima kategori yang dapat dilihat dari tabel berikut :

Tabel 4: Kriteria Keberhasilan dari Hasil Belajar Siswa

\begin{tabular}{ccc}
\hline No & Tingkat Keberhasilan & $\begin{array}{c}\text { Predikat } \\
\text { Keberhasilan }\end{array}$ \\
\hline 1 & $86-100$ & Sangat Tinggi \\
2 & $71-85$ & Tinggi \\
3 & $56-70$ & Sedang \\
4 & $41-55$ & Rendah \\
5 & $<40$ & Sangat Rendah \\
\hline
\end{tabular}

(Sumber : adaptasi dari Agip dkk.2009:41)

\section{Indikator Keberhasilan}

Penelitian penerapan video media interaktif ini dapat dinyatakan berhasil atau dihentikan apabila telah tercapai indikator yang diharapkan. Sesuai kurikulum 2013, KKM adalah 70 dengan ketuntasan belajar suatu mata pelajaran adalah $75 \%$. Kriteria keberhasilan dalam penelitian ini adalah sebagai berikut:

1. Motivasi Belajar Belajar Siswa

a. Siklus I, motivasi belajar siswa mencapai persentase $57.86 \%$. dengan kriteria cukup termotivasi.

b. Siklus II, motivasi belajar siswa mencapai persentase $79.10 \%$. dengan kriteria termotivasi.

2. Hasil Belajar Siswa

a. Siklus I, hasil belajar siswa dengan rata-rata 70.24 dengan kriteria sedang.

b. Siklus II, hasil belajar siswa dengan rata-rata 86.37 dengan kriteria sangat tinggi. 


\section{HASIL DAN PEMBAHASAN}

\section{A. Deskripsi data}

Penelitian Ini dilaksanakan di SMK Negeri 1 Bukitiinggi pada tanggal 5 November sampai dengan 26 November 2018. Sampel digunakan siswa kelas XI Teknik Pengelasan dengan jumlah 29 orang siswa. pembelajaran dengan menggunakan video media ineraktif dilaksanakan selama dua siklus.

\section{B. Hasil Penelitian}

\section{Siklus I}

a). Pertemuan pertama siklus I pada tanggal 5 November 2018.

Pelajaran Shield Metal Arc Welding selama 3 jam pelajaran (1 x 45 menit). Materi yang dibahas mengenai pengertian pengelasan dan prosedur dalam pengelasan.

Tabel 5: Distribusi Frekuensi motivasi Belajar Siswa Pada pertemuan I Siklus I

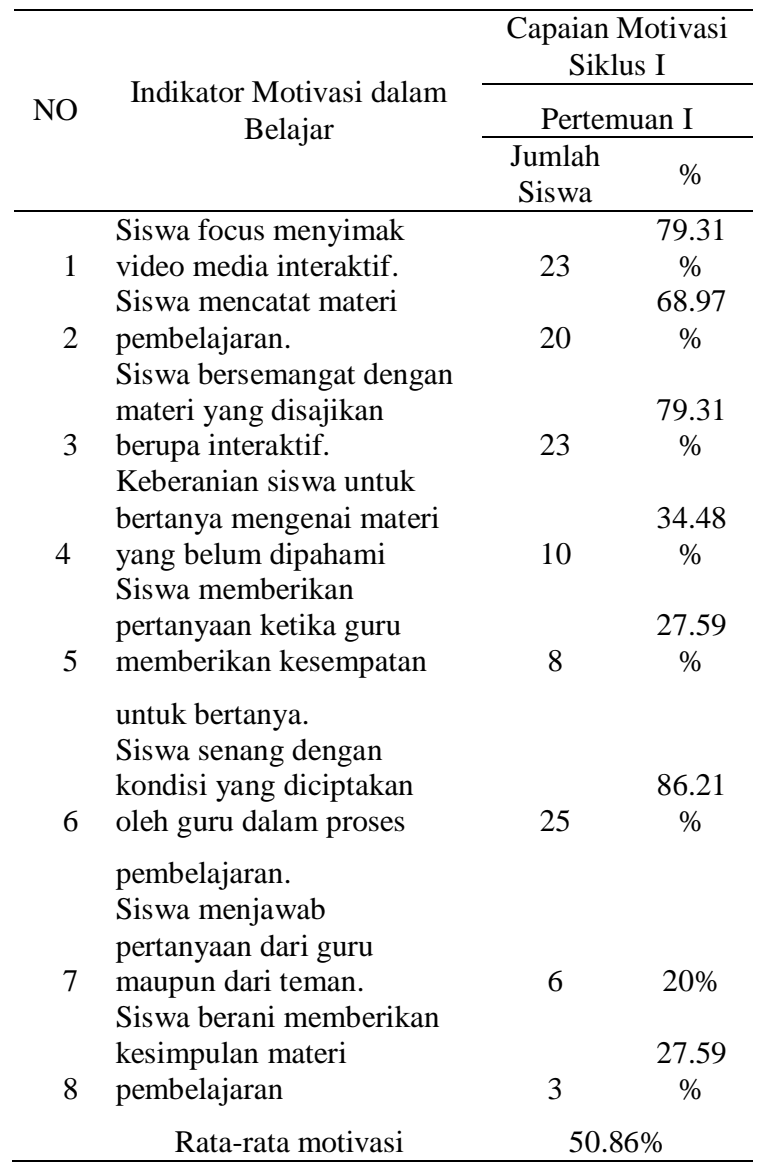

Hasil motivasi belajar siswa pada pertemuan I siklus I adalah $50.86 \%$ dengan kategori kurang termotivasi.

b). Pertemuan Kedua siklus I pada tanggal 12 November 2018. Pelajaran Shield Metal Arc Welding selama 3 jam pelajaran (1 x 45 menit). Materi tentang posisi dalam pengelasan dan alat bantu pengelasan.
Tabel 6: Distribusi Frekuensi motivasi Belajar Siswa Pada pertemuan II Siklus I

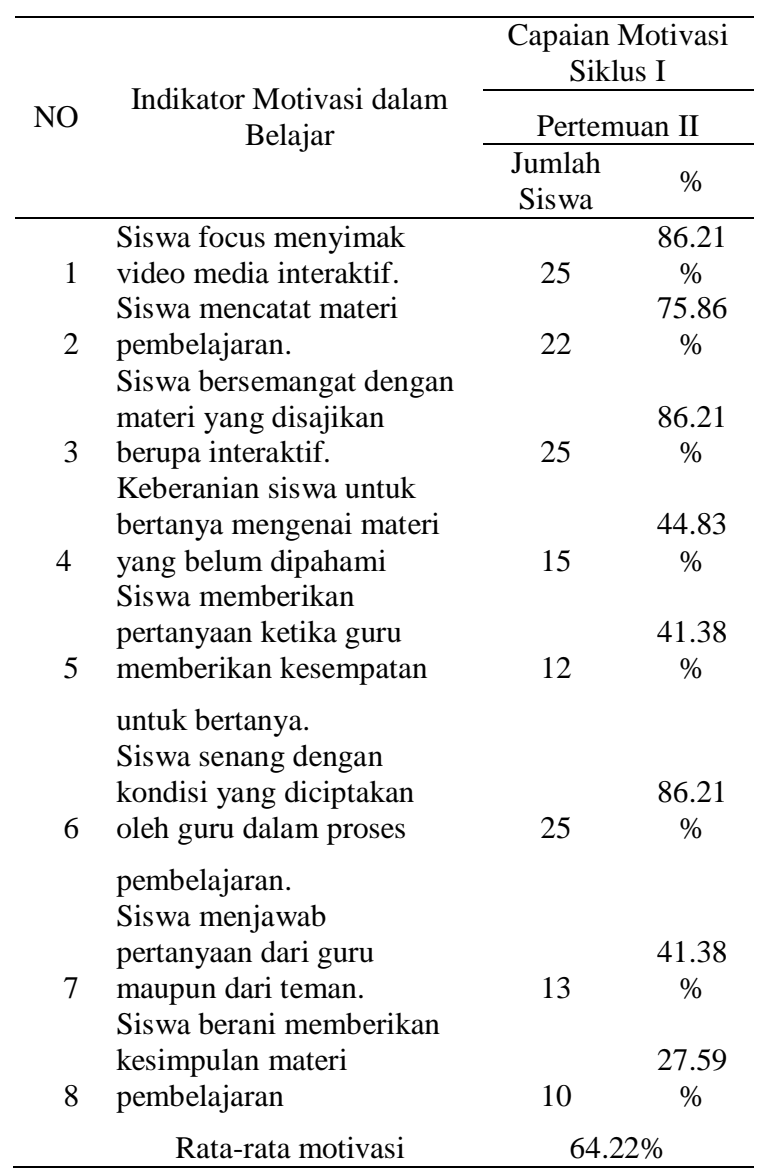

Motivasi belajar siswa pada pertemuan II siklus I adalah $64.22 \%$ dengan kategori cukup termotivasi.

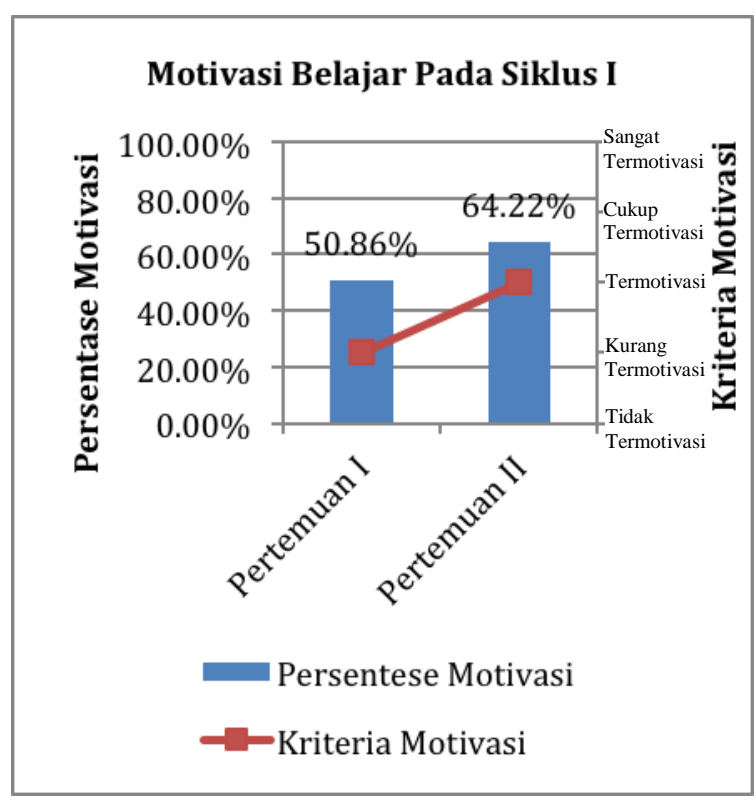

Gambar 1. Grafik Frekuensi Motivasi Belajar Siswa pada Siklus I

Hasil motivasi belajar pada pertemuan I siklus I adalah $50.86 \%$ dengan kriteria kurang termotivasi dan pertemuan II adalah $64.22 \%$ dengan kriteria 
cukup termotivasi. Dapat disimpulkan pada siklus I adalah $57.54 \%$ dengan kategori cukup termotivasi.

Tabel 7: Distribusi Frekuensi Hasil Belajar Siswa pada Siklus I

\begin{tabular}{|c|c|c|}
\hline \multirow{2}{*}{ NO } & \multirow{2}{*}{ Nama } & \multirow{2}{*}{$\begin{array}{l}\text { Nilai } \\
\text { Tes } 1\end{array}$} \\
\hline & & \\
\hline 1 & A I & 75 \\
\hline 2 & A R & 57.5 \\
\hline 3 & AAA & 70 \\
\hline 4 & E S & 77.5 \\
\hline 5 & F R & 67.5 \\
\hline 6 & F Y & 70 \\
\hline 7 & F S & 75 \\
\hline 8 & F M A & 67.5 \\
\hline 9 & F S & 70 \\
\hline 10 & F M & 67.5 \\
\hline 11 & G R & 65 \\
\hline 12 & GF R & 85 \\
\hline 13 & J I & 87.5 \\
\hline 14 & K H & 75 \\
\hline 15 & M F H & 80 \\
\hline 16 & M R P N & 60 \\
\hline 17 & M F F & 82.5 \\
\hline 18 & M R & 65 \\
\hline 19 & M S & 50 \\
\hline 20 & $\mathrm{~N}$ & 60 \\
\hline 21 & O S & 60 \\
\hline 22 & P D J & 80 \\
\hline 23 & R H & 77.5 \\
\hline 24 & R S & 57.5 \\
\hline 25 & R RR & 75 \\
\hline 26 & R I & 72.5 \\
\hline 27 & S P & 77.5 \\
\hline 28 & $\mathrm{TH}$ & 67.5 \\
\hline 29 & W R & 65 \\
\hline Nilai te & rrendah & 50 \\
\hline Nilai te & rtinggi & 87.5 \\
\hline Rata-rc & & 70.24 \\
\hline
\end{tabular}

Hasil penilaian siklus I dengan materi pengertian pengelasan, prosedur dalam pengelsan, posisi dalam pengelasan dan alat bantu dalam pengelan, didapatkan rata-rata kelas yang diperoleh adalah 70,24 , skor tertinggi yang diperoleh adalah 87,5 dan skor terendah 50. Berdasarkan KKM yang ditetapkan yakni 70 terlihat dari 29 orang siswa hanya $55 \%$ yang tuntas dan $45 \%$ belum tuntas.

\section{Siklus II}

a) Pertemuan pertama siklus II dilaksanakan pada tanggal 19 November 2018. Pelajaran Shield Metal
Arc Welding dilaksanakan selama 3 jam pelajaran (1 x 45 menit). Materi yang dibahas merupakan materi lanjutan sesuai silabus yakni cacat dalam pengelasan.

Tabel 8: Distribusi Frekuensimotivasi Belajar Siswa Pada pertemuan I Siklus II

\begin{tabular}{|c|c|c|c|}
\hline \multirow{3}{*}{ NO } & \multirow{3}{*}{ Indikator Motivasi dalam Belajar } & \multicolumn{2}{|c|}{$\begin{array}{l}\text { Capaian Motivasi } \\
\text { Siklus II }\end{array}$} \\
\hline & & \multicolumn{2}{|c|}{ Pertemuan I } \\
\hline & & $\begin{array}{l}\text { Jumlah } \\
\text { Siswa } \\
\end{array}$ & $\%$ \\
\hline 1 & $\begin{array}{l}\text { Siswa focus menyimak video } \\
\text { media interaktif. }\end{array}$ & 27 & $\begin{array}{c}93.10 \\
\% \\
93.10\end{array}$ \\
\hline 2 & $\begin{array}{l}\text { pembelajaran. } \\
\text { Siswa bersemangat dengan }\end{array}$ & 27 & $\%$ \\
\hline 3 & $\begin{array}{l}\text { materi yang disajikan berupa } \\
\text { interaktif. } \\
\text { Keberanian siswa untuk bertanya }\end{array}$ & 27 & $\begin{array}{c}93.10 \\
\%\end{array}$ \\
\hline 4 & $\begin{array}{l}\text { mengenai materi yang belum } \\
\text { dipahami } \\
\text { Siswa memberikan pertanyaan }\end{array}$ & 18 & $\begin{array}{c}62.07 \\
\%\end{array}$ \\
\hline 5 & $\begin{array}{l}\text { ketika guru memberikan } \\
\text { kesempatan }\end{array}$ & 14 & $\begin{array}{c}41.38 \\
\%\end{array}$ \\
\hline 6 & $\begin{array}{l}\text { untuk bertanya. } \\
\text { Siswa senang dengan kondisi } \\
\text { yang diciptakan oleh guru dalam } \\
\text { proses }\end{array}$ & 27 & $\begin{array}{c}93.10 \\
\%\end{array}$ \\
\hline 7 & $\begin{array}{l}\text { pembelajaran. } \\
\text { Siswa menjawab pertanyaan dari } \\
\text { guru maupun dari teman. } \\
\text { Siswa berani memberikan }\end{array}$ & 15 & $\begin{array}{l}51.72 \\
\% \\
55.17\end{array}$ \\
\hline 8 & kesimpulan materi pembelajaran & 16 & $\%$ \\
\hline & Rata-rata motivasi & 73.7 & \\
\hline
\end{tabular}

Hasil observasi menunjukkan motivasi belajar siswa pada pertemuan I siklus II adalah $73.71 \%$ dengan kategori cukup termotivasi.

b) Pertemuan Kedua

Pertemuan kedua siklus II dilaksanakan pada tanggal 26 November 2018. Pelajaran Shield Metal Arc Welding dilaksanakan selama 3 jam pelajaran $(1 \mathrm{x}$ 45 menit).

Tabel 9: Distribusi Frekuensimotivasi Belajar Siswa Pada pertemuan II Siklus II

\begin{tabular}{|c|c|c|c|}
\hline \multirow{3}{*}{$\mathrm{NO}$} & \multirow{3}{*}{$\begin{array}{c}\text { Indikator Motivasi dalam } \\
\text { Belajar }\end{array}$} & \multicolumn{2}{|c|}{$\begin{array}{c}\text { Capaian Motivasi } \\
\text { Siklus II }\end{array}$} \\
\hline & & \multicolumn{2}{|c|}{ Pertemuan I } \\
\hline & & $\begin{array}{l}\text { Jumlah } \\
\text { Siswa }\end{array}$ & $\%$ \\
\hline 1 & $\begin{array}{l}\text { Siswa focus menyimak } \\
\text { video media interaktif. } \\
\text { Siswa mencatat materi }\end{array}$ & 29 & $100 \%$ \\
\hline 2 & $\begin{array}{l}\text { pembelajaran. } \\
\text { Siswa bersemangat dengan }\end{array}$ & 29 & $100 \%$ \\
\hline 3 & $\begin{array}{l}\text { materi yang disajikan } \\
\text { berupa interaktif. }\end{array}$ & 29 & $\begin{array}{c}93.10 \\
\%\end{array}$ \\
\hline
\end{tabular}




\begin{tabular}{|c|c|c|c|}
\hline \multirow{3}{*}{4} & Keberanian siswa untuk & \multirow[b]{2}{*}{24} & \multirow{2}{*}{$\begin{array}{c}82.76 \\
\%\end{array}$} \\
\hline & yang belum dipahami & & \\
\hline & $\begin{array}{l}\text { Siswa memberikan } \\
\text { pertanyaan ketika guru }\end{array}$ & & 62.07 \\
\hline 5 & memberikan kesempatan & 18 & $\%$ \\
\hline 6 & $\begin{array}{l}\text { untuk bertanya. } \\
\text { Siswa senang dengan } \\
\text { kondisi yang diciptakan } \\
\text { oleh guru dalam proses }\end{array}$ & 29 & $100 \%$ \\
\hline & $\begin{array}{l}\text { pembelajaran. } \\
\text { Siswa menjawab } \\
\text { pertanyaan dari guru }\end{array}$ & & 62.07 \\
\hline 7 & $\begin{array}{l}\text { maupun dari teman. } \\
\text { Siswa berani memberikan }\end{array}$ & 18 & $\%$ \\
\hline 8 & $\begin{array}{l}\text { kesimpulan materi } \\
\text { pembelajaran }\end{array}$ & 20 & $\begin{array}{c}68.97 \\
\%\end{array}$ \\
\hline & Rata-rata motivasi & & \\
\hline
\end{tabular}

Siklus II pertemuan I $73.71 \%$ dan pertemuan II $84.48 \%$, persentase motivasi siswa pada siklus II ini adalah $79.10 \%$ tergolong kepada termotivasi.

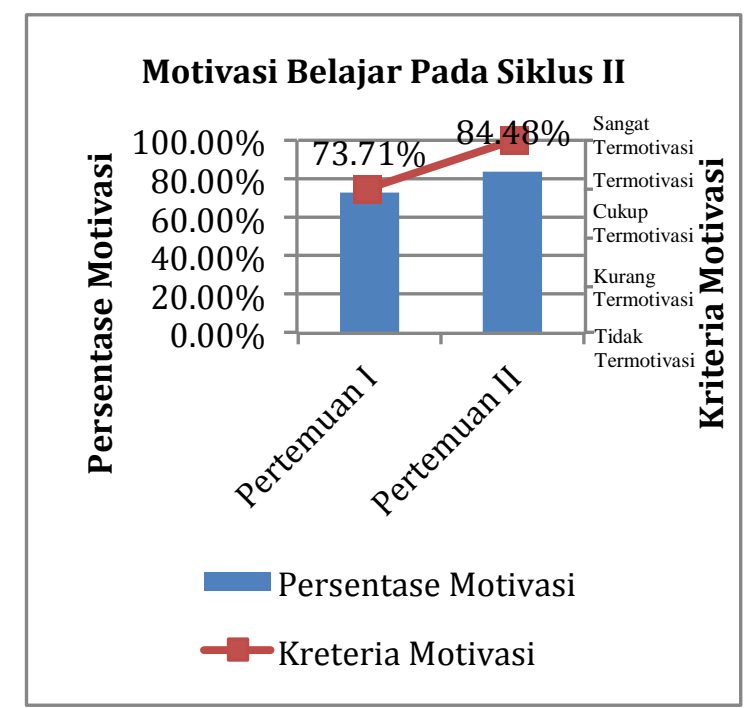

Gambar 2. Grafik Frekuensi Motivasi Belajar Siswa pada Siklus II

Tabel 10: Distribusi Frekuensi Hasil Belajar Siswa pada Siklus I

\begin{tabular}{|c|c|c|}
\hline \multirow{2}{*}{ NO } & \multirow{2}{*}{ Nama } & Nilai \\
\hline & & Tes 2 \\
\hline 1 & A I & 92.5 \\
\hline 2 & AR & 80 \\
\hline 3 & $\mathrm{~A} A \mathrm{~A}$ & 87.5 \\
\hline 4 & E S & 92.5 \\
\hline 5 & fF R & 85 \\
\hline 6 & F Y & 95 \\
\hline 7 & F S & 87.5 \\
\hline 8 & F A M & 90 \\
\hline 9 & F S & 82.5 \\
\hline 10 & F M & 92.5 \\
\hline 11 & G R & 85 \\
\hline
\end{tabular}

\begin{tabular}{llc}
12 & G F R & 97.5 \\
13 & J I & 97.5 \\
14 & K H & 87.5 \\
15 & M F H & 90 \\
16 & M R P N & 77.5 \\
17 & M FF & 85 \\
18 & M R & 80 \\
19 & M S & 70 \\
20 & N & 77.5 \\
21 & O S & 72.5 \\
22 & P D J & 97.5 \\
23 & R H & 97.5 \\
24 & R S & 80 \\
25 & R RR & 87.5 \\
26 & R I & 97.5 \\
27 & S P & 90 \\
28 & T H & 75 \\
29 & W R & 85 \\
& Nilaiterrendah & 70 \\
& Nilaitertinggi & 97.5 \\
& Rata-rata & 86.37 \\
\hline
\end{tabular}

\section{Pembahasan}

Pada bagian ini dilakukan pembahasan hasil penelitian yang dipaparkan di atas. Fokus pembahasannya adalah peningkatan hasil pembelajaran dan motivasi belajar siswa menggunakan video media interaktif pada materi Sheild Metal Arc Welding di kelas XI Teknik Pengelasan SMK Negeri 1 Bukittinggi.

1. Pembahasan siklus I

Motivasi siswa pada siklus I ini adalah $57.86 \%$ yang tergolong kurang termotivasi dan hasil belajar siswa diperoleh rata-rata 70.24. Melihat perolehan tersebut, motivasi dan hasil belajar siswa tergolong cukup, oleh karena itu dilakukan perbaikan agar video pembelajaran dapat meningkatkan penasaran dan motivasi siswa serta mengurangi kerancuan pada video media interaktif pada siklus I.

\section{Pembahasan Siklus II}

Motivasi siswa dalam belajar pada siklus II ini adalah $79.10 \%$ yang tergolong termotifasi. Sedangkan Hasil belajar siswa diambil dari tes untuk mengukur tingkat pemahaman siswa. Pada siklus II dengan rata-rata yakni 86.37. Setelah dibandingkan motivasi dan hasil belajar siswa dari siklus I sampai siklus II terdapat peningkatan di setiap pertemuan, baik pada siklus I maupun siklus II. Hal ini membuktikan bahwa dengan video media ineraktif dapat meningkatkan motivasi dan hasil belajar siswa. Untuk lebih jelasnya peningkatan Motivasi 
dan hasil belajar siswa pada siklus I dan II dapat dilihat pada gambar berikut:

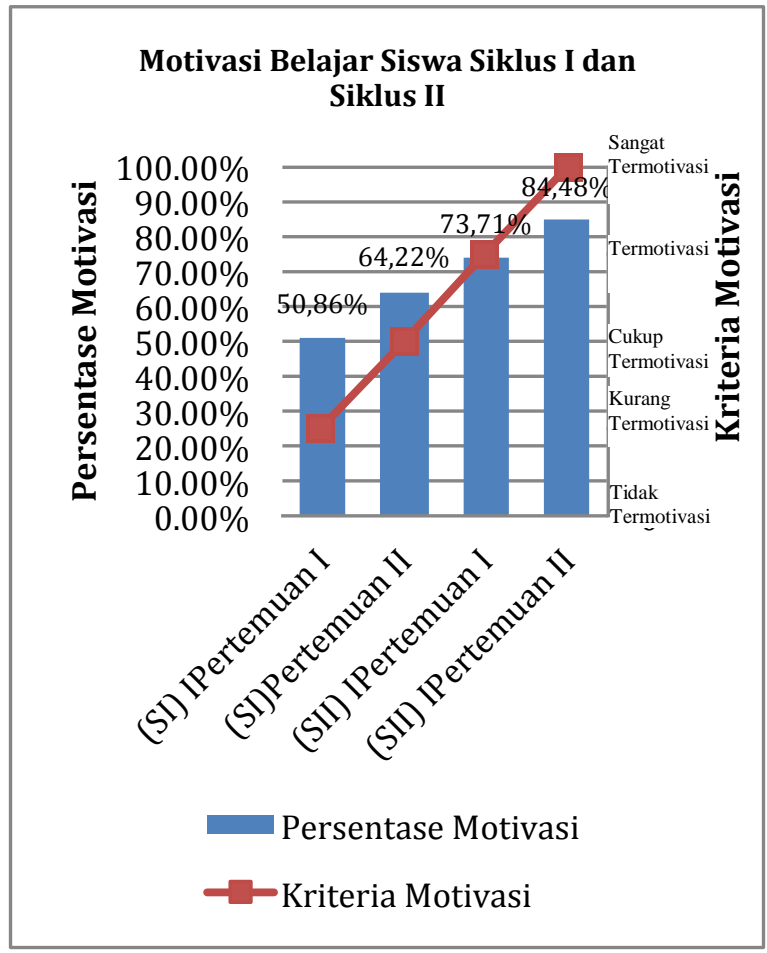

Gambar 3. Grafik Frekuensi motivasi Belajar Siswa pada Siklus I dan II

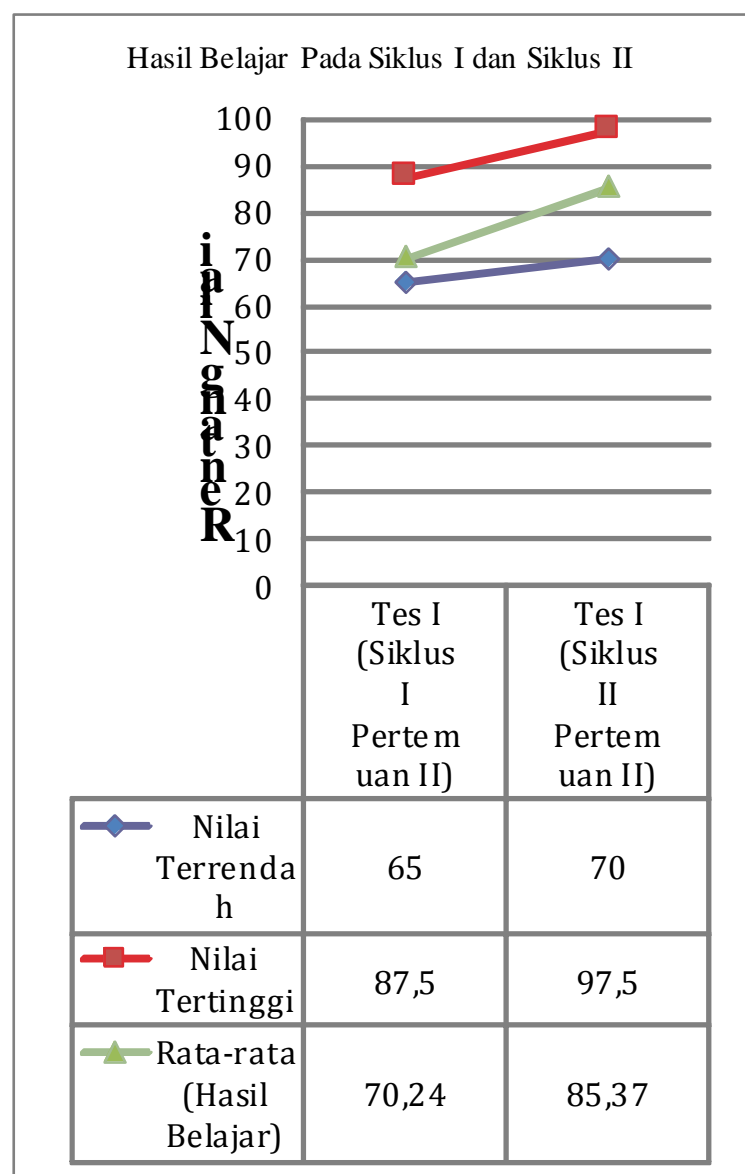

Gambar 4. Grafik Frekuensi Hasil Belajar Siswa pada Siklus I dan II
3. Refleksi pada Siklus I dan Siklus II

Refleksi merupakan perbaikan pembelajaran yang bertujuan untuk memperbaiki kekurangan pada siklus sebelumnya.

Tabel 11. Perbaikan Siklus I dan Siklus II

\begin{tabular}{|c|c|c|c|c|}
\hline $\mathrm{N}$ & \multicolumn{2}{|c|}{ Siklus I } & \multicolumn{2}{|c|}{ Siklus II } \\
\hline o & Kendala & Pengaruh & Perbaikan & Pengaruh \\
\hline 1 & Audio & $\begin{array}{l}\text { Suara } \\
\text { yang di } \\
\text { hasilkan } \\
\text { tidak jelas } \\
\text { terdengar } \\
\text { oleh siswa }\end{array}$ & Audio & $\begin{array}{l}\text { Mengguna } \\
\text { kan speker } \\
\text { yang } \\
\text { layak } \\
\text { dengan } \\
\text { audio } \\
\text { jernih }\end{array}$ \\
\hline 2 & Infokus & $\begin{array}{l}\text { Visual } \\
\text { yang } \\
\text { ditampilka } \\
\mathrm{n} \text { kurang } \\
\text { jelas }\end{array}$ & Infokus & $\begin{array}{l}\text { Menggant } \\
\mathrm{i} \text { infokus } \\
\text { yang } \\
\text { bagus }\end{array}$ \\
\hline$\overline{\mathrm{N}}$ & & is I & & \\
\hline o & Kendala & Pengaruh & Perbaikan & Pengaruh \\
\hline 3 & Video & $\begin{array}{l}\text { Video } \\
\text { yang } \\
\text { ditampil } \\
\text { kan pada } \\
\text { satu } \\
\text { materi } \\
\text { masih } \\
\text { menggunk } \\
\text { an satu } \\
\text { video }\end{array}$ & Video & $\begin{array}{l}\text { Video } \\
\text { lebih } \\
\text { beragam } \\
\text { Pada } \\
\text { setiap } \\
\text { materi nya }\end{array}$ \\
\hline
\end{tabular}

\section{KESIMPULAN}

Penggunaan video media interaktif untuk meningkatkan motivasi dan hasil beajar siswa pada mata pelajaran Shield Metal Arc Welding terbukti dapat meningkatkan motivasi dan hasil belajar kelas XI Teknik Pengelasan SMK Negeri 1 Bukittinggi. Capaian pembelajaran

Shield Metal Arc Welding menggunakan video media interaktif akan diuraikan sebagai berikut:

Motivasi siswa dalam belajar Shield Metal Arc Welding di kelas XI Teknik Pengelasan SMK Negeri 1 Bukittinggi dengan menggunakan video media interaktif mengalami kenaikan yaitu motivasi belajar siswa pada siklus I pertemuan I adalah $50.86 \%$ dengan kriteria kurang termotivasi; siklus I pertemuan II adalah $64.22 \%$ dengan kriteria cukup termotivasi; dan pada siklus II pertemuan adalah I $73.71 \%$ dengan kriteria termotivasi; siklus II pertemuan adalah II $84.48 \%$ dengan kriteria sangat termotivasi. Jadi terdapat peningkatan motivasi belajar siswa dari siklus I sampai siklus II.

Hasil belajar siswa pada mata pelajaran Shield Metal Arc Welding kelas XI Teknik Pengelasan SMK Negeri 1 Bukittinggi dengan menggunakan video sebagai media interaktif mengalami kenaikan 
yaitu rata-rata nilai hasil belajar siswa pada siklus I dengan nilai rata-rata 70.24; dan pada siklus II nilai rata-rata 86.53. Jadi terdapat peningkatan hasil belajar siswa tergolong baik.

\section{DAfTar Pustaka}

[1].Arikunto,Suharsimi. 2001. Metode Penelitian : Prosedur Penelitian Suatu Pendekatan Praktek. Jakarta : Rineka Cipta. Gravindo Persada.

[2].__ 2010. Prosedur Penelitian Suatu Pendekatan Praktik.Jakarta: Rineka Cipta.

[3].Arsyad,, Azhar. 2014. Media Pembelajaran. Jakarta : PT. Raja Grafindo Persada.

[4].Anas Sudijono. 2008. Pengantar Evaliasi pendidikan. Jakarta : Raja Gravindo.

[5].Ambiyar $d k k$ (2016). Penerapan Model Pembelajaran Praktek Terbimbing Mata Diklat Las Busur Manual Untuk Meningkatkan Aktivitas dan Hasil Belajar Praktek Siswa Kelas XI JurusanTeknik Mesin SMK Muhammadiyah 1 Padang. Jurnal Pendidikan Teknik Mesin. UNP.

[6].Bulkia Rahim (2018). Pengembangan Perangkat Pembelajaran Berbasis Model PJBL pada Mata Diklat Teknik Digital. Jurnal Pendidikan Teknik Mesin. UNP.

[7].Bambang dan Cecep Kusnandi. 2002. Strategi Belajar Mengajar. Jakarta : Rineka Cipta.

[8].Dimyati \& Mujiono. 1994. Belajar dan Elliot, John. 1982. Developing Hypothesis about Classroom from Teachers Practical Constucts; an Account of The work or the Ford Teaching Project. The Action Research Reader. Deakin University. Geelong Victoria.

[9].Gibson, Ivancervick, Donelly. 1985. Organisasi, Prilaku, Struktur, Proese. Terjemahan oleh Drs. Djarkasih, MPA. 1996. Jakarta : Penerbit Erlangga.

[10]. Jasman, Dkk (2018). Studi Kualitas Input Siswa dan Suasana Belajar terhadap Hasil Belajar Mata Pelajaran Pengelasan Siswa SMK N 1 Sumatera Barat. Jurnal Pendidikan Teknik mesin. UNP.
[11]. Nana Sudjana. (2002). Penelitian Hasil Proses Belajar Mengajar. Bandung: Remaja Rosdakarya.

[12]. Nizwardi Jalinus $d k k$ (2018) Pengaruh Model Pembelajaran Problem Solving dan Motivasi Berprestasi Terhadap Hasil Belajae Fisika Siswa SMK Negeri 1 Lahat. Jurnal Pendidikan Teknik Mesin. UNP.

[13]. Mulianti (2018). Kompetensi Lulusan Vokasi: Analisis Validitas dan Reliabilitas Indikator. Jurnal Pendidikan Teknik Mesin. UNP.

[14]. Refdinal dkk (2018) Pengaruh Model Pembelajaran Problem Solving dan Motivasi Berprestasi Terhadap Hasil Belajae Fisika Siswa SMK Negeri 1 Lahat. Jurnal Pendidikan Teknik Mesin. UNP.

[15]. Setyo Hari. 2008. Pengaruh Budaya Organisasi, Tingkat Hirarki Moral dan Motivasi Terhadap Komitmen Guru. Jurnal Universitas Mulawarman.

[16]. Sudjijono,Anas. 2008. Pengantar Evaluasi Pendidikan. Jakarta : Raja Grafindo Persada.

[17]. Sugiyono. 2010. Metode Penelitian Kuantitatif, Kualitatif, $R \& D$. Bandung : Alfabeta

[18].__ 2012. Metode Penelitian Pendidikan:Pendekatan Kuantitatif, Kualitatif, dan $R \& D$. Bandung :Alfabeta

[19]. Suparno (2017). Respon Mahasiswa Pembelajaran Kooperatif Jigsaw dan Modul Pembelajaran Pada Mta Kuliah Media Pendidikan. Jurnal Pendidikan Teknik Mesin. UNP.

[20]. Yufrizal (2011). Penerapan Model Pembelajaran Think-Pair-Share untuk Meningkatkan Hasil Belajar Mahasiswa Pada Mata Kuliah Teknik Mesin FTUNP. Jurnal Pendidiakn Teknik Mesin. UNP.

[21]. Waskito dkk (2016). Kontribusi Minat Kerja dan Penguasaan Mata Pelajaran Produktif terhadap Keberhasilan Praktek Kerja Industri Siswa Kels XII Program Keahlian Teknik Permesinan SMK Negeri 2 Solok. 